\title{
Chapter 11 \\ How Transnational are Migrants in Switzerland? An Analysis of the Migration-Mobility-Transnationality Nexus
}

\author{
Eric Crettaz and Janine Dahinden
}

\subsection{Introduction}

Since the early 1990s, a new debate has unfolded within the field of migration studies pointing to a new phenomenon - "transnationalism" - which, as scholars argued, had been neglected by migration studies. In particular, Glick Schiller and her colleagues argued that contemporary migrants should not be characterized as being "uprooted", as was generally assumed in the classical assimilation theory. Rather, they are transmigrants, becoming firmly rooted in their new country but maintaining simultaneously multiple linkages to their homeland. They bring together their societies of origin and settlement (Glick Schiller et al. 1992; Basch et al. 1994). In due course, transnational studies have proliferated, and the transnational perspective has become one of the fundamental means of understanding the contemporary practices of migrants occurring across national borders (Faist et al. 2013; Vertovec 2009); however, their modest theoretical essence and often descriptive contextdependent analyses have been criticized (Portes et al. 1999; Waldinger 2015). For this chapter, we will address three shortcomings of this field of research.

E. Crettaz $(\bowtie)$

School of Social Work, University of Applied Sciences and Arts of Western Switzerland,

Geneva, Switzerland

nccr-on the move, Neuchâtel, Switzerland

e-mail: Eric.Crettaz@hesge.ch

J. Dahinden

Laboratory for the Study of Social Processes, University of Neuchâtel,

Neuchâtel, Switzerland

nccr-on the move, Neuchâtel, Switzerland

e-mail: Janine.Dahinden@unine.ch

(C) The Author(s) 2019

I. Steiner, P. Wanner (eds.), Migrants and Expats: The Swiss Migration and Mobility Nexus, IMISCOE Research Series,

https://doi.org/10.1007/978-3-030-05671-1_11 
First, most of the literature relies on qualitative case studies, whereas quantitative studies remain rare. The latter have shown that transnationality ${ }^{1}$ is far from being a "lifestyle" of migrants as it appeared in the 1990s. Not every migrant is "transnational", neither in terms of networks nor in terms of activities, practices or feelings of belonging (Guarnizo et al. 2003; Portes et al. 2002; Dahinden 2005, 2009). In line with this research strand, we ask: How transnational are the migrants living in Switzerland? How can we characterize those who are most transnational and those who are the least, and how can we explain these different degrees and forms of transnationality?

Second, most studies in this field focus on one (or a few) nationally defined group(s) and then elaborate in a descriptive way on the transnationality of this/these group(s). This approach is problematic under two aspects: First, it prevents the creation of an overall theoretical model. Second, it is problematic because of the national- or ethno-centred epistemology (Wimmer and Glick Schiller 2002; Dahinden 2016). Therefore, we propose here an analysis of migrant transnationality among a broad range of migrants living in Switzerland, thanks to the MobilityMigration Survey, performed within the framework of the nccr - on the move, to elaborate explanatory models for transnationality going beyond nationality.

Finally, highlighting different patterns of transnationality requires a theoretical framework that captures not only migration, but also mobility more generally: For this reason, we apply a "mobility lens" (Urry 2007). The traditional migration framework often ignores that migrants are also mobile, in terms of pre-migration but also post-migration mobilities (Dahinden 2010b; Hui 2016; Moret 2018; Schapendonk 2015). In other words, our analysis contributes to this book by investigating the Migration-Mobility-Nexus with respect to transnationality, going beyond normative ideas by integrating them analytically into one model.

Section 11.2 introduces the assumptions and conceptual reflections we find in the literature concerning transnationality. In Sect. 11.3 we present the dataset and the indicators used, and descriptive statistics in Sect. 11.4. Because the main factors contributing to transnationality are correlated and because we aim at going beyond mere descriptions, we performed regression models in Sect. 11.5 and were able to identify the most and the least transnational groups among the studied migration population. Finally, we conducted a multiple correspondence analysis (see Sect. 11.6), allowing us to understand in detail how these various factors interact, leading to the identification of five ideal types of "transnational migrants". In a nutshell, our analysis confirms that transnationality can be linear, resource-dependent or reactive. In other words, transnationality can simultaneously be a sign not only of possessing high resources - in terms of legal capital, education and economic resources - but also of discrimination. Migration regimes and educational skills are of utmost importance concerning high or low degrees of transnationality - however, occasionally in unexpected combinations.

\footnotetext{
${ }^{1}$ Although the first vague references in the literature talked of "transnationalism", we use here - in line with other scholars (among others Faist et al. 2013; Glick Schiller 2004) - the term "transnationality". The latter term points to the dynamic, historical variable and constructed nature of the phenomenon, whereas terms with the ending -ism are often subjected to ideological connotations rather than analytical perspectives (such as capitalism, socialism, and multiculturalism).
} 


\subsection{Some Assumptions and Hypotheses About Migrant Transnationality}

Pries (2008) called for a clear operationalization of the concept of "transnationality". For this reason, we define transnationality as being composed of three dimensions: transnational mobilities in transnational spaces, transnational social relationships, and feelings of attachment towards the country of origin. In other words, being transnational involves (a) a mode of being mobile, (b) ways of being in terms of acting and performing (i.e., building up and maintaining transnational social relationships) and (c) ways of belonging (see also Levitt and Glick Schiller 2004). Considering all three aspects of transnationalism allows us to identify a diverse range of transnational formations and to detect their underlying mechanisms.

First Dimension: Transnational Mobilities Migration research has been highly influenced by a sedentarist bias due to methodological nationalism and the reproduction of the nation-state logic (Dahinden 2016; Hui 2016; Chavel 2014; Wimmer and Glick Schiller 2002). From a traditional migration perspective, the absence of mobility appears to be the norm, if not the ideal, assuming that a period of displacement is automatically preceded by a phase of sedentarity and followed by a process of settlement and mobility is reduced to the migration journey (Dahinden 2010a, 2012). In a similar reading, mobility is occasionally reserved to Europeans or highly skilled persons, whereas migration is associated with unqualified people, reproducing the normative political categories of desired and non-desired migrants (critically see Faist 2013). More recently, scholars have pointed to the continuous mobility processes of individual migrants and to crucial pre- and post-migration mobilities (Schapendonk 2015; Moret 2015). From the perspective of the "mobility studies" (Urry 2007; Cresswell 2010), migration is only one form of mobility among others. We argue that to understand transnationality - and to investigate how mobile the migrants living in Switzerland have been and remain, and who are the most and who the least mobile - we must include pre- and post-migration mobilities.

Second Dimension: Transnational Social Relationships The idea of transnationality emerged from the realization that migration does not lead to cutting social relationships; in contrast, they are maintained, reinforced or reinvented across borders, before and after migration (Vertovec 2009). Hence, we propose to examine transnational social networks at two points in time: before and after arriving in Switzerland. These two perspectives relate to two different fields of research within the transnational migration literature. First, since the 1960s, researchers have emphasized the fact that personal networks can be understood as conduits of information and social and financial assistance, thereby shaping, sustaining and channelling migration (Boyd 1989; Massey et al. 1993). One crucial dimension is so-called "chain migration" (Massey et al. 1993); social networks are channelling migrants to places in 
which they know persons who can support them when they arrive, concerning housing, jobs and other fields. Hence, we analyse transnational relationships that have channelled individuals to Switzerland. Second, we investigate the transnational relationships currently maintained by migrants, hence after immigration. We are interested not only in the extent of network transnationality but also in the question of who are the most transnational and who are the least transnational concerning networks. Here, we primarily focus on "core transnational relationships" (Levitt and Jaworsky 2007), meaning on the most durable social relationships, to the detriment of social relationships that are mobilized only occasionally.

Third Dimension: Feelings of Attachment Towards the Country of Origin ${ }^{2}$ Although we know from the literature that durable and stable transnational relationships often decline with the duration of stay and between generations (Kivisto 2001), transnational forms of belonging are more durable over time (Gowricharn 2009; Wessendorf 2010). Consequently, we investigate how attached the population under study is to their country of origin and who are the most and who are the least attached.

Linear, Resource-Dependent or Reactive Transnationality? We find in the literature different hypotheses concerning the mechanisms underlying different degrees of transnationality. The first hypothesis maintains that transnationality is a logical and inevitable consequence of migration and hence that it is "linear": migration does not mean a rupture with the country of origin. Rather, immigrants maintain automatically and simultaneously ties with their countries of origin (or a third country) and develop multiple forms of belonging. Likewise, it is argued that the duration of stay affects this linear transnationality; the longer the migrants stay in the receiving country, the more transnationality fades away (Kivisto 2001).

A second set of hypotheses is based on the finding that not all migrants develop and maintain transnationality to the same extent because transnationality depends upon the economic, cultural and social resources of migrants (Al-Ali et al. 2001; Dahinden 2009), on degrees and forms of discrimination and marginalization (Itzigsohn and Gioguli Saucedo 2005; Dahinden 2005) and of nation-state migration regimes and border politics (Waldinger and Fitzgerald 2004). Ideas of solidarity, reciprocity and belonging are also crucial for the establishment and maintenance of transnationality (Dahinden 2010b; Faist 2000). In other words, transnationality might be "linear", but it might also be "resource-dependent" (Itzigsohn and Gioguli Saucedo 2005). Studies showed that it is often the best integrated into the labour market, the naturalized, and the best educated, who are the most transnational. Conversely, transnationality might also be the result of discrimination and marginalization and therefore "reactive" (Snel et al. 2016).

\footnotetext{
${ }^{2}$ See sect. 11.3 on methodology for data limitations concerning transnationality beyond countries of origin.
} 
We will follow these ideas and assess, for all three dimensions of transnationality, the hypotheses of linear/source-dependent/reactive transnationality among the studied migrant population.

\subsection{Data and Methods}

The following analyses are based on the Migration-Mobility Survey, performed within the framework of the National Centre of Competence for Research nccr - on the move. Data collection was carried out in the fall of 2016. Persons who arrived in Switzerland over the past 10 years and who are foreign nationals born abroad were interviewed. The stratified sampling approach allows for a satisfactory representativeness of 11 groups defined by the country/region of origin and interviewed in six different languages and for a weighting scheme based on the selection probability, participation rate and adjusted for the size of the reference population. All results presented in this chapter are based on weighted data. ${ }^{3}$ Only individuals of working age (between 24 and 65 years old) were interviewed.

Here are the 12 variables we used to operationalize transnationality and its three main dimensions ('I' stands for indicator):

Concerning mobility itself:

I1. Number of international moves (linked to stays of at least 3 months in another country) before coming to Switzerland for the current stay

I2. Frequency of visits to the country of origin since the arrival in Switzerland

Concerning transnational relationships before coming to Switzerland:

I3. Whether respondents followed a partner when coming to Switzerland

I4. Whether respondents had relatives already living in Switzerland before they arrived

... and after immigration we include questions asking whether respondents:

I5. Have a partner living abroad (transnational intimate relationship)

I6. Have children living abroad (transnational parenthood)

I7. Have good friends living abroad, and how many transnational friendship relationships

Finally, for attachment, interest and involvement:

I8. How homesick respondents felt when they arrived in Switzerland (0-7 scale)

I9. How much they feel attached to their country of origin (0-7 scale)

I10. If they feel at home when they visit their country of origin today (from the first day, it takes an adjustment period, feels like a tourist or visitor)

\footnotetext{
${ }^{3}$ For more details concerning the origin groups, interview languages, weighting procedure, and further statistical aspects, see Chap. 2 in this volume.
} 
I11. If and how much they are interested in news and current events in the country of origin ( $0-7$ scale)

I12. If and how much they are involved in political activities in the country of origin (various political activities are mentioned as further detailed in Sect. 11.4.3)

There is one important limit concerning the data of the Migration-Mobility Survey. We had to concentrate our analysis on the country of origin. There are no responses in the data concerning multipolar mobilities or feelings of attachment beyond the country of origin.

Concerning the explanatory variables, we focussed on the following factors:

The region of origin ${ }^{4}$ as a proxy for migration regimes, border politics and legal capital (Glick Schiller and Salazar 2013; Moret 2015), which have an effect on mobility, migration and transnationality. Legal capital means having the "right passport" to be able to be mobile and not be touched by migration restrictions. ${ }^{5}$ Switzerland is characterized by a dual dynamic; due to the bilateral agreements with the European Union, European citizens have unlimited mobility, whereas for so-called third-country nationals, important legal barriers to entering the country and to being mobile exist. Hence, we assume that EU citizens are also transnationally more mobile. ${ }^{6}$ Also related to migration regimes is the type of residence permit (settlement (C), residence (B), short-term (L), diplomat/international civil servant (DFAE)/and their families (Ci)), each endowed with a certain set of rights.

Educational level (no post-compulsory education/secondary/tertiary degree) is an important variable in terms of resources because it is an asset that allows overcoming migration restrictions; being highly qualified can be an entry ticket to Switzerland (for non-European citizens).

Whether respondents feel they have been discriminated against in Switzerland, gender and the labour market status (in labour force/in training/out of the labour force) are further variables included in the analysis.

\footnotetext{
${ }^{4}$ We have used the country of birth to define this variable. In $94 \%$ of cases, the country of birth corresponds to the "country of origin" self-defined by the respondents.

${ }^{5}$ See the global passport power ranking, https://www.passportindex.org/byRank.php. Accessed 16 June 2018.

${ }^{6} \mathrm{We}$ have further regrouped nationalities/origins as follows: Northern and Western Europe (Germany, France, Austria, Netherlands, Belgium, Luxembourg, UK, Ireland, Sweden, Denmark, Norway, Finland, and Iceland); Southern EU (Italy, Spain, Portugal, Malta, Greece, and Cyprus); Western Balkans and Turkey (Kosovo, Serbia, Macedonia, Bosnia-Herzegovina, Albania, Montenegro, and Turkey); Eastern and Central EU (Bulgaria, Baltic countries, Czech Republic, Croatia, Poland, Romania, Hungary, Slovakia, and Slovenia); and South and Central America (all American countries but the United States and Canada, classified as North America). In the cases of Africa and Asia, we used standard geographical divisions. The groupings are due to the fact that, for most nationalities, the number of cases is too restricted to draw reliable conclusions; in addition, the analysis has more to do with the type of countries rather than specific countries (EU vs. non-EU, high-income countries vs middle-income, politically stable region vs unstable, and the like).
} 
Furthermore, we included variables that directly affect those resources, notably through processes of accumulation, such as respondent's age (split into ten-year brackets) and length of the stay in Switzerland.

We will start by displaying descriptive statistics in Sect. 11.4 pertaining to three main dimensions of transnationality - mobility, social networks and attachment. Then, we use regression models in Sect. 11.5 that allow us to determine which characteristics make people more - or less - transnational, that is, the impact of each factor when the others are controlled for. In a last but important step (Sect. 11.6), we use multiple correspondence analysis to identify combinations of transnationality patterns and of common sociodemographic characteristics to identify ideal-typical situations.

\subsection{Transnational Mobility, Networks and Feelings of Attachment}

\subsubsection{Pre- and Post-migration Transnational Mobility}

The first indicator focusses on pre-migration mobility (see Table 11.1). Most respondents have already spent at least 3 months in a country other than Switzerland or their country of origin before moving to Switzerland. ${ }^{7}$

Fifty-four percent of respondents have already moved once or twice internationally, $37 \%$ three to five times, and $7.5 \%$ more than five times. In other words, we find a type of generalized mobility among migrants in Switzerland, which is striking because there are no reasons to believe, in light of the methodological procedures used to select the sample, that very mobile persons should be overrepresented in the sample.

The second indicator pointing to transnational mobility, however to postmigration mobility, concerns the number of visits to the (self-defined) country of origin, which shows that most of this population is very mobile (see Table 11.1). Although only $7.7 \%$ never visited their country of origin, most respondents return one to two times (39\%) or even three to six times (35\%) per year. Eighteen percent circulate at least once per month.

In summary, we find a highly generalized mobility among migrants living in Switzerland, which points to two elements: first, migration is accompanied by multiple forms of mobility and, second, mobility is more generalized than is usually assumed in the literature, in which it is often reduced to the highly skilled population.

\footnotetext{
${ }^{7}$ Before moving to Switzerland refers to the question, "Except for Switzerland and your country of birth, in how many countries have you lived for 3 months or more?" This question is completed by "Is it the first time you have lived in Switzerland for three or more months". In the event of several stays, the analysis refers to the current stay in Switzerland.
} 
Table 11.1 Pre- and post-migration behaviour (in \%)

\begin{tabular}{l|l|c}
\hline Indicator & Categories & Distribution \\
\hline $\begin{array}{l}\text { Number of international moves before the arrival in } \\
\text { Switzerland (I1) }\end{array}$ & $\begin{array}{l}\text { Never moved } \\
\text { internationally }\end{array}$ & 1.9 \\
\cline { 2 - 3 } & Once or twice & 54.0 \\
\cline { 2 - 3 } & 3-5 times & 36.7 \\
\cline { 2 - 3 } & 6+ times & 7.5 \\
\hline Frequency of visits to the country of origin (I2) & No visit since arrival & 7.7 \\
\cline { 2 - 3 } & 1-2 times per year & 39.2 \\
\hline & 3-6 times per year & 35.1 \\
\hline & At least once per month & 18.1
\end{tabular}

Source: Migration-Mobility Survey 2016. Weighted results

\subsubsection{Transnational Networks}

Let us now move on to the second dimension, namely transnational social networks. We initially turn to the channelling and migration sustaining effect of transnational relationships before migration. One strong factor for this channelling effect is the fact of joining a partner/spouse already living in Switzerland (see Table 11.2).

One-third of respondents who were in a relationship when they moved to Switzerland state that they have moved to Switzerland together (32\%), but it is more common that one partner moved before the other (40\%). In addition, some have met their partner in Switzerland (15\%), and others have their partner (still) living abroad $(13 \%)$. The case we are interested in here is that of persons who joined a partner ${ }^{8}$ who moved first to Switzerland. This scenario represents $21 \%$ of the population under study.

Concerning the role of networks in sustaining migration, people other than the partner are also of obvious relevance. Respondents were asked whether they had relatives in Switzerland when they arrived, and we cross tabulate this information with that in Table 11.3. Three in ten had relatives in Switzerland; only approximately $10 \%$ followed a partner/spouse and had other relatives in Switzerland. These numbers appear rather low given the importance of "chain migration" in the literature.

Concerning today's transnational social relationships, important information pertains to respondents' partners' country of residence (see Table 11.4).

Surprisingly, we observe that only a small minority (14\%) are involved in an intimate transnational relationship. Another indicator of network transnationality concerns transnational parenthood. Fifty-three percent of respondents have children, and they were asked whether their children live in Switzerland:

\footnotetext{
${ }^{8}$ This reason mentioned by respondents is self-reported and hence not linked to the residence permit.
} 
Table 11.2 Did respondents come before, after or at the same time as their partners to Switzerland (in \%)

\begin{tabular}{l|l}
\hline & Distribution \\
\hline $\begin{array}{l}\text { Your spouse/partner already lived in } \\
\text { Switzerland }\end{array}$ & 15.4 \\
\hline You moved together & 31.7 \\
\hline Your spouse/partner moved before you & 20.7 \\
\hline Your spouse/partner moved after you. & 19.2 \\
\hline $\begin{array}{l}\text { Your spouse/partner has not yet moved } \\
\text { to Switzerland }\end{array}$ & 13.1 \\
\hline
\end{tabular}

Source: Migration-Mobility Survey 2016. Weighted results

Table 11.3 Relatives and/or partner already living in Switzerland when respondents arrived (in $\%)$

\begin{tabular}{l|l|l|r}
\hline & Had relatives in Switzerland & Did not have relatives & Total \\
\hline Did not follow partner/spouse & 19.2 & 60.1 & 79.3 \\
\hline Followed partner/spouse & 10.5 & 10.2 & 20.7 \\
\hline Total & 29.7 & 70.3 & 100.0 \\
\hline
\end{tabular}

Source: Migration-Mobility Survey 2016. Weighted results

Approximately one in six (16.5\%) migrants have children living abroad, again a low number that however corresponds to the result we presented concerning transnational intimate relationships.

Because preliminary analyses showed that the sociodemographic profiles linked to transnational intimate relationships and transnational parenting were similar, we created a variable "core family abroad". This category includes individuals whose partners and children live abroad (coded 2), who either have children or a partner living abroad (coded 1), whose partners live abroad and do not have children (also coded 1), or whose children live abroad and do not have a partner (also coded 1). Respondents who have neither children nor a partner are obviously excluded from the analysis. All other respondents are assigned a value of zero.

Thirty-one percent of respondents have their "core family" abroad; however, having both one's partner and children abroad is quite rare (only 5\%). Twenty-six percent have either a partner abroad and children in Switzerland, or children abroad and a partner in Switzerland, or a partner abroad and no children at all, or children abroad but no partner at all.

Finally, another very important component of transnational social networks can consist of "good friends" (defined by respondents). Compared with the indicators concerning transnational family aspects we discussed earlier, Transnational friendship is measured as $53 \%$ of respondents reporting having all or most of their good friends abroad (see Table 11.4).

In summary, chain migration is rather low. Moreover, transnational intimate relationships and parenting represent a minority phenomenon. Conversely, transnational friendships are more widespread. 
Table 11.4 Transnational social relationships (in \%)

\begin{tabular}{|c|c|c|}
\hline Indicator & Categories & Distributions \\
\hline \multirow{10}{*}{$\begin{array}{l}\text { Country of residence of respondent's } \\
\text { partner/spouse (I5) }\end{array}$} & Switzerland & 86.2 \\
\hline & Northern \& Western Europe & 6.2 \\
\hline & Southern EU & 6.1 \\
\hline & $\begin{array}{l}\text { Western Balkans (w/o Croatia) and } \\
\text { Turkey }\end{array}$ & 0.1 \\
\hline & Eastern \& Central European Union & 0.1 \\
\hline & North America & 0.2 \\
\hline & Africa & 0.3 \\
\hline & South \& Central America & 0.2 \\
\hline & Asia & 0.4 \\
\hline & Other & 0.3 \\
\hline \multirow[t]{3}{*}{ Place of residence of children (I6) } & Does not have children & 46.7 \\
\hline & Has children living in Switzerland & 36.8 \\
\hline & Has children living abroad & 16.5 \\
\hline \multirow[t]{3}{*}{$\begin{array}{l}\text { Place of residence partner and } \\
\text { children (I5/I6) }\end{array}$} & $\begin{array}{l}\text { Partner and children in Switzerland (if } \\
\text { applies) }\end{array}$ & 69.4 \\
\hline & $\begin{array}{l}\text { Either the partner only, or the children } \\
\text { only live abroad }\end{array}$ & 25.6 \\
\hline & Partner and children live abroad & 5.0 \\
\hline \multirow[t]{5}{*}{$\begin{array}{l}\text { Place of residence of good friends } \\
\text { (I7) }\end{array}$} & $\begin{array}{l}\text { All your good friends live in Switzerland } \\
(\mathrm{CH})\end{array}$ & 3.7 \\
\hline & Most of your good friends live in $\mathrm{CH}$ & 11.2 \\
\hline & $\begin{array}{l}\text { Approximately the same numbers of } \\
\text { friends in } \mathrm{CH} \text { and abroad }\end{array}$ & 32.5 \\
\hline & Most of your good friends live abroad & 36.0 \\
\hline & All your good friends live abroad & 16.5 \\
\hline
\end{tabular}

Source: Migration-Mobility Survey 2016. Weighted results

\subsubsection{Transnational Feelings of Attachment, Interest and Involvement}

As mentioned above, three indicators give us a sense of how respondents feel attached to their country of origin (namely I8, I9, and I10). Because exploratory descriptive analyses showed that the three questions were very similar in terms of differences across the various sociodemographic categories, we created an attachment index that combines them, which required transforming the variable "do you feel at home when you visit your country of origin" into a 0-7 scale ${ }^{9}$ and then calculating the unweighted mean of these three 0-7 scales. The answers were then regrouped into brackets and distributed as displayed in Table 11.5.

\footnotetext{
${ }^{9}$ The answer "Feels at home from first day on" was assigned a value of 7, "At home after an adjustment" a value of 3.5, and "Like a tourist/visitor" a value of zero.
} 
Table 11.5 Transnational feelings of attachment, interest and involvement (in \%)

\begin{tabular}{l|l|l}
\hline Scale & Attachment Index 0-7 & $\begin{array}{l}\text { Degree of involvement and interest } \\
\text { (country of origin, index 0-7) }\end{array}$ \\
\hline 0 & 3.7 & 4.3 \\
\hline 1 & 7.1 & 10.7 \\
\hline 2 & 8.9 & 24.6 \\
\hline 3 & 14.2 & 33.1 \\
\hline 4 & 26.8 & 12.3 \\
\hline 5 & 19.9 & 10.3 \\
\hline 7 & 13.6 & 2.1 \\
\hline
\end{tabular}

Source: Migration-Mobility Survey 2016. Weighted results

Approximately one-fifth of respondents give the lowest answers (0-2), approximately two-fifths indicate a medium degree of attachment (3 and 4), and two-fifths a high degree of attachment (5-7). Overall then, the degree of attachment is quite strong, although a non-negligible minority appears to be quite detached, subjectively speaking, from their countries of origin.

Respondents were also asked to say how much they are interested in news and current events in their country of origin and to indicate their involvement in political activities in that country. Previous analyses showed again that I11 and I12 led to similar conclusions in sociodemographic terms; hence, we generated an Interest/ Involvement Index (hereafter III). In a first step, we identified stronger and more organized involvement (sign a petition, make a donation, participate in a demonstration, contact a politician, or work in an association, political party or action group). These answers were assigned a value of 7 . The other activities receive a value of 3.5, whereas respondents who were not involved in any activity received a value of 0 .

Approximately $40 \%$ of respondents express a low interest/involvement (answers 0-2), whereas one in seven expresses a high degree (answers 5-7), with $45 \%$ displaying intermediate levels.

To summarize, the dimension linked to feelings of belonging is clearly the one displaying the highest level of transnationality. Feelings of attachment to the country of origin are strong among migrants, although some are detached. Belonging, measured through the interest in news and current events or in terms of political engagement in the country of origin, is linked to a lower degree of transnationality; however, it remains higher than do other forms of transnationality analysed in this chapter.

Having now described the main dimensions of transnationality, we want to learn who among our respondents are the most and the least transnational and the reason(s) for this status, which is the purpose of the next section. 


\subsection{Regression Models}

The goal of this section is to identify by means of linear regressions (OLS) the sociodemographic characteristics that make people more or less transnational. The transnationality indicators described above have been standardized to be measured on a scale from 0 to 10 , with 0 always applied to the least transnational group and 10 to the most transnational one; for continuous variables, this approach is straightforward. For qualitative variables, we proceeded as follows. For a dichotomous variable, the values given are 0 and 10; for variables with three answers, the values are 0, 5 and 10; for four answers, 0, 3.333, 6.666, and 10; and for five answers, $0,2.5,5,7.5$, and 10 .

If we focussed the analysis on respondents who had to give an answer to each question included in our indexes, we would lose five-sixths of the sample. For instance, some respondents did not have children or a partner for the reference period of the question, whereas others refused to answer one or several questions. Hence, we have decided to include:

- People who only answered the second question of dimension 1 (i.e., those who had not moved internationally before coming to Switzerland)

- People who have at least two out of four answers on the second dimension (some only have two if they do not have a partner or children)

- People who answered at least three of the five questions on the third dimension

An examination of the OLS regression residuals shows a distribution close to the normal distribution, and residuals do not appear to present a specific challenge. ${ }^{10}$ Although most sociodemographic variables are correlated with one another, this correlation does not pose a problem in terms of multicollinearity. ${ }^{11}$

We ran four regression models - one for each dimension of transnationality, and the fourth addresses overall transnationality (see Table 11.6). For most variables, the table shows the impact of having a characteristic other than that of the reference category. The year of birth has been entered in a quadratic form (year $\left.+y^{2} \mathrm{r}^{2}\right)$ to detect non-linear evolutions over time, and the same has been done with the year of arrival in Switzerland.

The region of origin plays a major role overall, even when controlling for a large array of sociodemographic characteristics. Being from Southern Europe rather than from Northern/Western Europe (the reference group) implies an overall higher degree of transnationality; however, this point holds for the second and third dimensions, but not for the first one. In fact, no one is more mobile than Northern/ Western Europeans. Southern Europeans distinguish themselves as being particularly attached to their countries of origin while maintaining strong transnational networks.

\footnotetext{
${ }^{10}$ However, data tend to be heteroskedastic. Because this characteristic does not appear to be attributable to a gross misspecification of the models and is more likely related to the standardization method, we chose to use robust standard errors to obtain reliable significance tests.

${ }^{11}$ The highest variance inflation factors hardly reach a value of 3 , which is clearly below the usual limits.
} 
Table 11.6 Determinants of the various forms of transnationality, effect on the 0-10 scales

\begin{tabular}{|c|c|c|c|c|c|c|c|c|}
\hline & \multicolumn{2}{|c|}{$\begin{array}{l}\text { Index 1: } \\
\text { Mobility }\end{array}$} & \multicolumn{2}{|c|}{$\begin{array}{l}\text { Index 2: Social } \\
\text { networks }\end{array}$} & \multicolumn{2}{|c|}{$\begin{array}{l}\text { Index 3: } \\
\text { Interested, } \\
\text { attached, } \\
\text { involved }\end{array}$} & \multicolumn{2}{|c|}{ Over-all index } \\
\hline & Coeff & Sig. & Coeff & Sig. & Coeff & Sig. & Coeff & Sig. \\
\hline \multicolumn{9}{|c|}{ Region of birth (Ref. North/West Europe) } \\
\hline Southern EU & -0.63 & $* * *$ & 0.29 & $* *$ & 0.74 & $* * *$ & 0.13 & $* *$ \\
\hline $\begin{array}{l}\text { Western Balkans } \\
\text { (without Croatia) and } \\
\text { Turkey }\end{array}$ & -1.58 & $* * *$ & -0.57 & $*$ & -1.07 & $* * *$ & -1.03 & $* * *$ \\
\hline Eastern \& Central EU & -1.96 & $* * *$ & -0.30 & & -1.16 & $* * *$ & -1.14 & $* * *$ \\
\hline North America & -1.82 & $* * *$ & -0.46 & $* * *$ & 0.33 & $* * *$ & -0.65 & $* * *$ \\
\hline Africa & -2.51 & $* * *$ & -0.49 & $* * *$ & -0.08 & & -1.03 & $* * *$ \\
\hline South \& Central America & -2.32 & $* * *$ & -0.42 & $* * *$ & 0.22 & $* *$ & -0.85 & $* * *$ \\
\hline Asia & -2.17 & $* * *$ & -0.08 & & 0.16 & & -0.70 & $* * *$ \\
\hline Other & -2.49 & $* * *$ & 0.27 & & -0.70 & $* *$ & -0.97 & $* * *$ \\
\hline Woman & -0.06 & & -0.05 & & 0.40 & $* * *$ & 0.10 & $* *$ \\
\hline \multicolumn{9}{|c|}{ Education (ref: no post-compulsory) } \\
\hline Secondary & 0.35 & $* * *$ & 0.12 & & -0.29 & $* *$ & 0.07 & \\
\hline Tertiary & 0.54 & $* * *$ & 0.56 & $* * *$ & -0.01 & & 0.38 & $* * *$ \\
\hline Birth year & -1.82 & & 2.22 & $*$ & 2.75 & $* *$ & 1.07 & \\
\hline Squared birth year & 0.00 & & -0.00 & $*$ & -0.00 & $* *$ & 0.00 & \\
\hline Year of arrival & -0.16 & $* * *$ & -0.21 & $* * *$ & -0.11 & $* *$ & -0.15 & $* * *$ \\
\hline Squared year of arrival & 0.01 & $* * *$ & 0.01 & $* *$ & 0.01 & & 0.01 & $* * *$ \\
\hline \multicolumn{9}{|c|}{ Current labour market situation (ref: in the labour force) } \\
\hline In training & -0.25 & $* *$ & 0.03 & & 0.11 & & -0.04 & \\
\hline Out of labour force & 0.02 & & -0.24 & $* * *$ & 0.07 & & -0.04 & \\
\hline \multicolumn{9}{|c|}{ Residence permit (Ref: C permit -settlement) } \\
\hline B permit - residence & -0.03 & & 0.18 & $* *$ & 0.07 & & 0.08 & \\
\hline $\begin{array}{l}\text { Diplomat or International } \\
\text { Status }\end{array}$ & 0.09 & & -0.07 & & 0.62 & $* *$ & 0.22 & $* *$ \\
\hline $\begin{array}{l}\text { L permit - short-term } \\
\text { stay }\end{array}$ & -0.34 & $*$ & 0.55 & $* *$ & 0.14 & & 0.13 & \\
\hline Has child(ren) & -0.26 & $* *$ & 0.34 & $* * *$ & 0.10 & & 0.06 & \\
\hline Has a partner & -0.02 & & 0.49 & $* * *$ & 0.21 & $* *$ & 0.23 & $* * *$ \\
\hline $\begin{array}{l}\text { Has experienced } \\
\text { discrimination }\end{array}$ & -0.13 & $* *$ & 0.18 & $* * *$ & 0.44 & $* * *$ & 0.16 & $* * *$ \\
\hline
\end{tabular}

Note: $* * *=$ significant at $1 \%$-level, $* *=5 \%, *=10 *$

${ }^{a}$ European Union Member States

Source: Migration-Mobility Survey 2016. Weighted results

This is interesting because, from a legal point of view, Southern, Eastern and Central Europeans are submitted to the same mobility regimes.

This situation does not hold, however, for transnational social networks because there is no difference between Northern/Western Europeans, Eastern/central Europeans and Asians, whereas people from other regions are less transnational on this dimension. On the third dimension (attachment, interest, and belonging), 
Southern Europeans, North Americans and Latin Americans are more transnational than are Northern/Western Europeans, whereas Africans and Asians are equally attached and interested. Interestingly, people from the Western Balkans and Eastern and Central Europe are the least attached.

Women are more transnational than men are overall, but this aspect is due to the third dimension of transnationality (attachment, interest, and involvement); they appear to be less mobile than men are, but the difference is not statistically significant. This result is interesting because we can nuance the conclusions found in the literature. Women might be less mobile or less involved in transnational networks, but it is not being a woman per se that matters but rather other characteristics of female migrants.

The highly educated are more transnational than others are, globally speaking. However, this point is primarily true for social networks and for mobility to a lesser extent. There is little difference concerning the third dimension; if anything, having an intermediary educational level leads to less attachment/interest/involvement than does having a lower or higher educational level. In general, this variable shows less effect than one would expect from the literature, which primarily relies on descriptive evidence.

Age has no effect per se on mobility and hardly any on transnational networks; separate tests not shown here indicate that its effect disappears once we control for the fact of having children and a partner/spouse. However, age has an effect on the index of attachment/interest/involvement; this index increases with age, but less so when respondents are closer to retirement age.

Duration of the stay has a curvilinear effect; those who have just arrived and those who have spent the most years in Switzerland are the most transnational, all else being equal, and this point holds for the first (mobility) and the second (networks) dimensions. For the third dimension, the longer the stay in Switzerland, the higher is the subjective transnationality.

Labour market status affects the mobility of those in training; they are less mobile than are those who are employed. This factor also affects those who are out of the labour force; they are less transnational in terms of networks, which points to missing resources. Indeed, persons who are out of the labour force and/or have lower incomes in Switzerland have smaller social networks and less frequent contacts (Gazareth and Modetta 2006).

Diplomats and other persons having an international status $(\mathrm{N}=106)$ are more transnational compared with residents holding a settlement permit (C permit). However, this point is largely due to the subjective dimension, and, surprisingly enough, not to mobility; the high average educational level of this category most likely explains this surprising result. There is one significant difference between B-permit holders (renewable five-year residence) and settlement permit holders (C permit), namely that the former are more transnational in terms of networks than the latter. Holders of short-term permits (L) stand out as being significantly less mobile, 
which is not surprising given their low "legal capital for mobility", and as being more transnational in terms of networks.

Having children reduces mobility and increases network transnationality, whereas having a partner affects networks and transnational belonging. Family reasons are therefore a strong predictor for transnationality.

Feeling discriminated against affects all three dimensions of transnationality; people are less mobile, and they are more involved in transnational networks and more attached to, and interested in, their country of origin, bearing in mind that we control for the region of origin (which can also be an indirect measure of "ethnicity").

What do these results tell us about the hypothesis of linear, resource-dependent and reactive transnationality?

First, concerning linear transnationality, we have evidence that in fact, among people who have been in Switzerland for 10 years at most, transnationality is generally a given, but on a rather low level (with the exception of transnational attachment). Additionally, the simple equation that the longer the stay, the less transnational, does not hold, bearing in mind that individuals who have been in Switzerland for more than a decade were not interviewed.

Second, we find elements sustaining the idea that transnationality is resourcedependent; concerning transnational mobility, legal capital in terms of having a European passport and having a settlement permit is indeed a predictor of a high degree of transnational mobility (the least mobile being people from Africa and Central America, and also those with a short-term permit). Education is a second element sustaining the hypothesis that transnational mobility is resource dependent, the highly skilled being the most mobile. Conversely, having children is a barrier to transnational mobility. A similar picture emerges concerning network transnationality; education is again a predictor for high network transnationality. Legal capital does however not appear on this dimension. Instead, resources related to the socio-economic situation appear to affect this dimension; being out of the labour force accompanies a low degree of network transnationality. Conversely, having children is a predictor for high network transnationality. Finally, concerning attachment to the country of origin, none of the following appears to have an effect: legal capital, education, or the situation in the labour market.

Finally, concerning the hypothesis of "reactive" transnationalism, we cannot identify higher degrees of transnationality in economically marginalized people; rather, they have a lower degree of transnationality as we described above. However, the feeling of having been discriminated against affects all three dimensions; it does not lead to higher mobility. In contrast, it leads to higher levels of network transnationality and attachment.

In Sect. 11.6, we will further deepen this analysis, showing how these different variables interact. This will give us a more in-depth insight into the mechanisms that lead to high or low degrees of transnational mobility, networks and attachments. 


\subsection{Towards a Typology of the Mobility-Migration- Transnationality Nexus}

The following results are based on multiple correspondence analysis (MCA), and on the same indicators of transnationality as in the regression models. This inductive statistical method projects the answers to the above-mentioned questions on a plane that is defined by the main axes that best summarize the information contained in each variable. The dimensions mentioned in the figures do not correspond to the dimensions of transnationalism mentioned above (mobility, transnational networks, transnational attachment and belonging); they are the result of the MCA. In Fig. 11.1, we connect the modalities of various transnationality indicators to observe how they contribute to the two main dimensions of the MCA.

Figure 11.1 shows that mobility defines both axes; today's mobility is strongly linked to the first axis, whereas the mobility prior to the move to Switzerland strongly defines the second axis.

Social networks define two diagonals; the first one goes from the upper left quadrant to the lower right one, from those who followed a partner and/or who had other relatives in Switzerland and/or who have their "core family" in Switzerland, to the opposite combination. The second one goes from the lower left quadrant to the upper right one, from those who have most or all good friends living in Switzerland to those who have most or all good friends living abroad.

In terms of transnational attachment, one diagonal emerges. It goes from the lower left quadrant to the upper right quadrant, from those who have a low level of attachment to the country of origin, a low degree of interest and low involvement in politics, to the opposite combination. This diagonal is almost congruent to the "most good friends abroad vs. most in Switzerland" diagonal.

Figure 11.2 identifies ideal typical combinations of transnational features by identifying five groupings that we have circled. In Fig. 11.3, we retain the same axes based on transnationality indicators, but project so-called supplementary variables, here the sociodemographic characteristics used as explanatory variables in the regression models.

The first ideal type in the upper left quadrant includes persons who moved to Switzerland when they had relatives and a partner there. They were and are the least mobile, are more likely to have their core family in Switzerland but have most of their friends in their country of origin and to be quite attached to it. Figure 11.3 shows that this ideal type most typically consists of young Southern Europeans who have recently arrived in Switzerland and who feel discriminated against. These persons are more likely to be women. We call this ideal type the immobile, one-time migrants with linear transnationality. This type also reflects the deep economic recession that hit Southern Europe, causing huge youth unemployment rates in these countries. This ideal type is the one that appeared as the "norm" in the early literature on transnationality. Glick Schiller and her colleagues (1995) understood the phenomenon as a reflection of basic political and economic global structural transformations and of particular power constellations. However, it is only one among five types. 


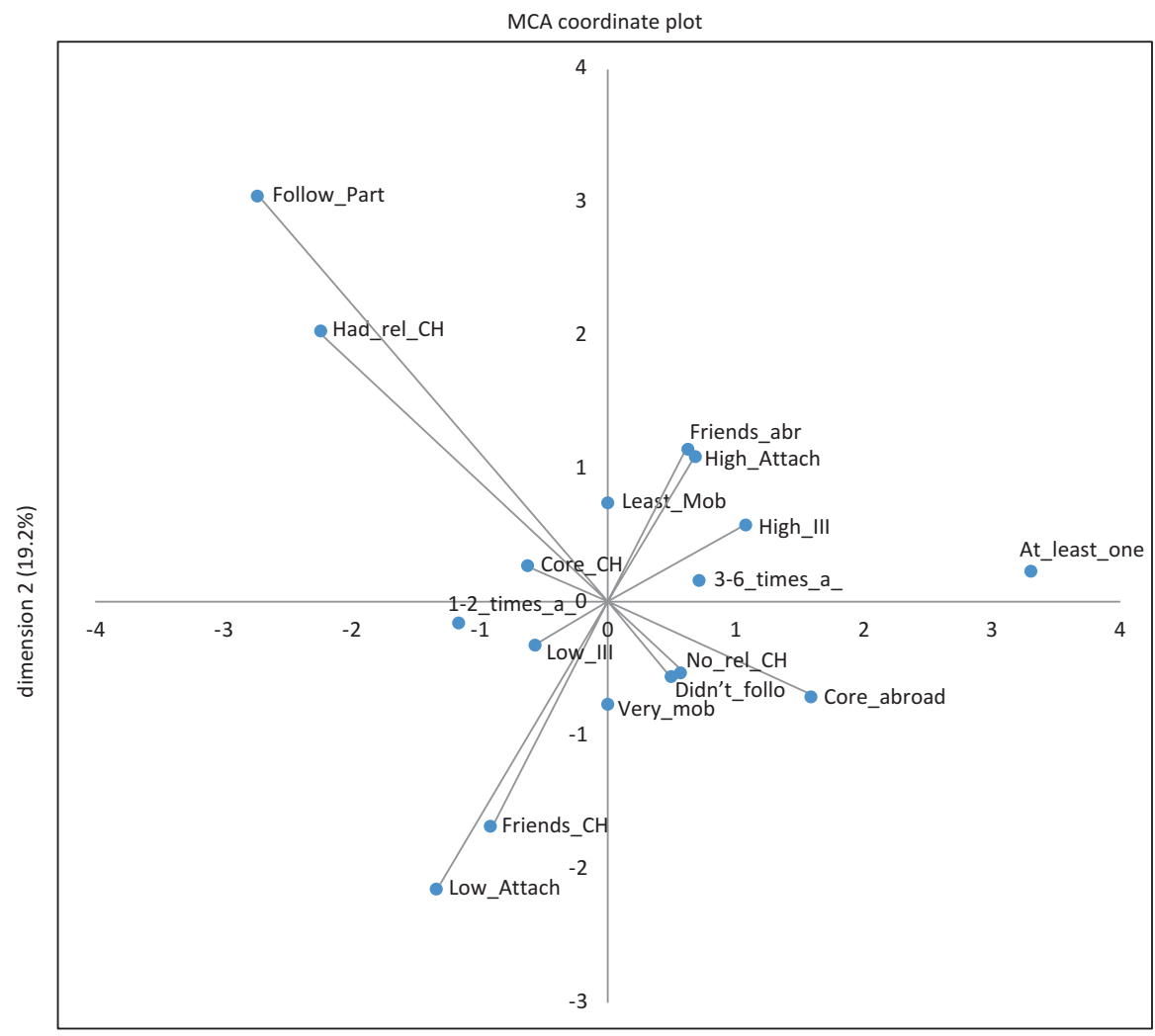

dimension 1 (37.0\%)

Least_Mob: 0 or 1 international move before coming to Switzerland

Very_mob: Two or more international moves

Core_abroad: children and/or partner abroad

1_2_times_a: goes to country of origin once or twice a year

3-6_times_a: three to six times a year

Core_CH: in Switzerland

Friends_abr: Most or all good friends live abroad

Friends_CH: most or all in Switzerland

At_least_one: at least once a month

Didn't_follo: Did not follow his/her partner to Switzerland

Low_Attach: low degree of attachment to country of origin (0 to 3.99)

High_Attach: high degree (4 to 7)

Follow_Part: followed partner

No_rel_CH: did not have relatives in Switzerland when arrived

Low III: low value on Interest-Involvement Index (0 to 3.99)

Had_rel_CH: had relatives in Switzerland when arrived

High III: high value (4 to 7 )

Fig. 11.1 Multiple correspondence analysis based on indicators of transnationality (active variables)

Source: Migration-Mobility Survey 2016 


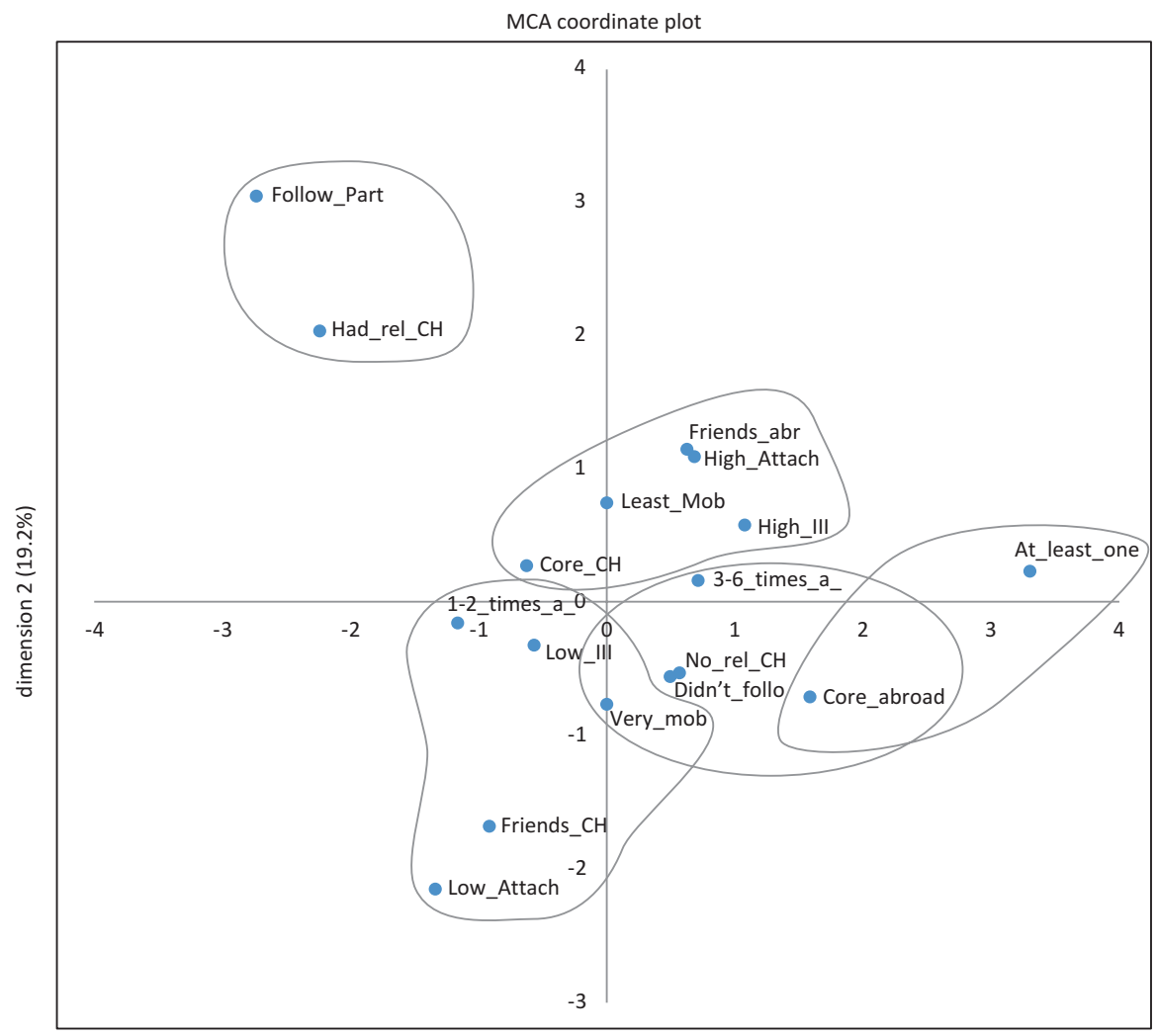

dimension 1 (37.0\%)

coordinates in standard normalization

Least_Mob: 0 or 1 international move before coming to Switzerland

Core_abroad: children and/or partner abroad

Very_mob: Two or more international moves

1_2_times_a: goes to country of origin once or twice a year

Core_CH: in Switzerland

Friends_abr: Most or all good friends live abroad

3-6_times_a: three to six times a year

At_least_one: at least once a month

Didn't_follo: Did not follow his/her partner to Switzerland

Follow_Part: followed partner

No_rel_CH: did not have relatives in Switzerland when arrived

Friends_CH: most or all in Switzerland

Low_Attach: low degree of attachment to country of origin (0 to 3.99)

High_Attach: high degree (4 to 7)

Low III: low value on Interest-Involvement Index (0 to 3.99)

Had_rel_CH: had relatives in Switzerland when arrived

High III: high value (4 to 7 )

Fig. 11.2 Ideal typical transnationality patterns Source: Migration-Mobility Survey 


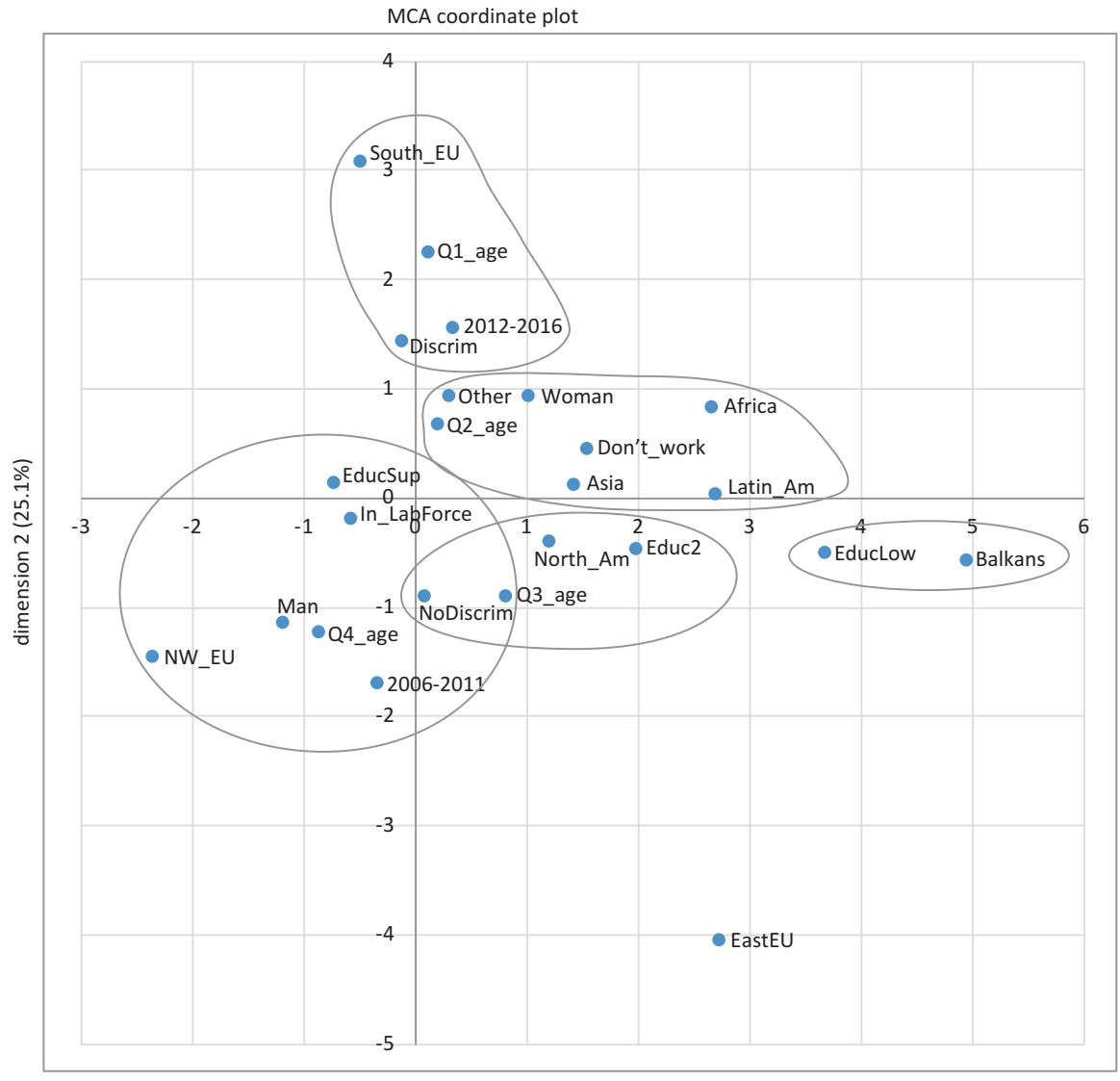

dimension 1 (36.7\%)

supplementary (passive) variables: woman RegionOB ExperienceDiscrimin NewEduc LMSitNow2 QuartilesAge YrsinCH coordinates in standard normalization

NW_EU: born in Northern/Western parts of European Union (EU) + Norway and Iceland

South_EU: Southern EU countries,

Balkans: Western Balkans + Turkey (but without Croatia)

EastEU: Eastern and Central EU countries (incl. Croatia)

North_Am: USA+Canada

Africa: the whole African continent

Latin_Am: Central and Southern America

Asia: all Asian countries

Other: other regions of origin

NoDiscrim: Has never been discriminated against in Switzerland

Discrim: has already been in this situation
EducLow: Compulsory education

Educ2: Intermediate education (vocational training and other non-tertiary education)

EducSup: Tertiary (university, college, etc.)

In_LabForce: holds a job

Don't_work: Unemployed or inactive i.e. not looking for a job

Q1_age: youngest quartile

Q2_age: youngest half of middle aged (second quartile)

Q3_age: oldest half of the middle aged (third quartile)

Q4_age: oldest quartile

2012_2016: arrived in Switzerland between 2012 and 2016

2006_2011: arrived before 2012

Fig. 11.3 Ideal typical sociodemographic composition of the types of transnationality identified in Fig. 11.2

Source: Migration-Mobility Survey 
The second ideal type is mostly found in the bottom left quadrant. It includes people who moved several times internationally before coming to Switzerland. These people are now far less mobile, most of their friends live in Switzerland, and they have a low degree of attachment to and of interest in their country of origin and of involvement in political activities in that country. They are more likely not to have had relatives and a partner in Switzerland when they arrived. As seen in Fig. 11.3, this second group is rather made up of highly educated men who are older than average, who do not feel discriminated against and who have been in Switzerland for at least 6 years. We could designate this type as the former very mobile men, now settled, non-transnational integrated migrants. This type essentially corresponds to the ideas of theories of integration maintaining that transnational networks and identifications would decline with duration of stay (Kivisto 2001).

The third ideal type is entirely on the right side of the figure. It includes persons who were not very mobile before coming to Switzerland but who are mobile now; their core family is abroad, and they have a strong attachment to, interest and involvement in their country of origin. This group typically contains women from Asia, Latin America, Asia, and North America to a lesser extent, who tend not to be in the labour force, have an intermediate educational level and are quite young to middle-aged, whereas Latin Americans are as close to the lowest educational level as they are to the intermediate educational level. We decided to call them the onetime migrants who are now mobile and transnationally attached to their core family abroad. This form of the Migration-Mobility-Transnationality Nexus is particularly gendered. It is primarily women who are implicated in transnational care chains (Hochschild 1983).

The fourth ideal type is on the bottom half of the figure, close to the first axis, and completely on the right of the vertical axis. This group includes the most mobile respondents, both before and after arriving in Switzerland, and they neither followed anyone to nor joined anyone in Switzerland. They are more likely to have their core family abroad and have an average level of attachment to, interest and involvement in their country of origin. This group most typically consists of persons from North America (and Asians are quite close, although we attributed them to the third type), who have an intermediate to high educational level, and belonging to this group is not a gendered phenomenon. We decided to call them the very mobile and cosmopolitan, not very transnationally attached. We can also find this group in the literature, in which it is called the "cosmopolite class" (Beck and Sznaider 2006) or the Eurostars (Favell 2008).

A fifth ideal type emerges. This type includes persons who are the most mobile now and were quite mobile previously. They are not particularly attached to their country of origin. They are typically from the Western Balkans and have a low educational level. They were more likely not to have followed their partner or to have joined relatives and are more likely to have their core family abroad now. Belonging to this group is not really gendered (although the answer 'women' is somewhat closer to this group than is "men"). We call them the hyper-mobile. They are not particularly attached; they are the transnational outsiders. They appear to 
circulate but not to be attached anywhere and not to have any resources. We could even designate this type "reactive mobility".

\subsection{Discussion and Conclusion}

The aim of this paper was to identify patterns of transnationality among migrants living in Switzerland. Having had the opportunity not to be limited to one national group allowed us to measure transnationality, to understand cross-group variations, and finally to present a typology of the Migration-Mobility-Transnationality Nexus.

Descriptive statistics showed that migration is accompanied by multiple forms of mobility and that transnational mobility is more generalized than usually assumed in the literature, in which it is often reduced to the highly skilled population. Data showed also that chain migration and transnational core family relationships are of minor importance. Conversely, transnational friendships are more widespread as a phenomenon. These results are rather surprising and call into question common assumptions about migrant networks; in general, family networks are considered more important than are friendship networks, although some recent studies have started to investigate the role of friendship networks in migration processes (Ryan 2015; Herz and Olivier 2012). Finally, transnational attachment to the country of origin and interest and involvement in news and politics are rather strong - even when a minority is clearly detached.

The regression models showed that being North/West European, or having a tertiary education, being in the labour market, having a settlement resident permit and not having children are predictors of a high degree of transnational mobility. Being African, from Central or South America, in training, or having a short-term permit in contrast is a predictor for a low degree of transnational mobility. The most transnational in terms of transnational networks are Southern Europeans, people with tertiary education and people having children. The least transnational on this dimension are people from the Western Balkans, North America, Africa and South and Central America, and those out of the labour force. Finally, people from Southern Europe and from Northern America, women and diplomats display high degrees of transnational attachment, but people who have lived the longest in Switzerland also display high degrees of transnational attachment.

These results primarily support the hypothesis that transnationality is resourcedependent and is to a lesser extent linear and reactive. The most important resources concerning transnational mobility are legal capital (European passport or settlement resident permit) and education. Children are a barrier for mobility. Transnational networks are also resource dependent, the most important elements here being education and being in the labour force. Finally, concerning transnational attachment, this hypothesis cannot really be confirmed.

Economically vulnerable people do not develop a "reactive" transnationalism; in contrast, they have rather low degrees of transnationality. However, the feeling of being discriminated against leads to strong transnational networks and attachment. 
Finally, multiple correspondence analysis yielded further insight into the Migration-Mobility-Transnationality Nexus. Five different ideal-typical configurations emerged, showing different combinations of the sociodemographic and economic variables; the first are the ideal-typical transmigrants of the first references in the literature, which we called the immobile, one-time migrants with linear transnationality. Second, an ideal type that fits the integration theory emerged, namely the former very mobile men, now settled, non-transnational integrated migrants. A gendered form of transnational care, namely the one-time migrants who are mobile and transnationally attached to their core family abroad is a third type. The "cosmopolites" constitute a forth type, namely the very mobile and cosmopolitan, not very transnationally attached. Finally, we identified transnational outsiders in which mobility appears reactive, the hyper-mobile not particularly attached.

Interestingly, there are two ideal types representing one-time migrants, whereas the three other types incorporate people who were mobile before coming to Switzerland. The one-time-migrant types are the most transnationally attached. In both cases, the probability is high that they are women and rather less educated. Here, this one-time and uni-linear migration occurred either in a situation of economic crisis (type 1) or in a situation of low legal capital (type 3, non-European women). These ideal types incorporate a form of either a linear or a reactive transnational attachment to the country of origin. The latter ideal type is interesting because it appears that post-migration mobility could contribute to maintain or reinforce transnational attachment.

The other three types incorporate much more mobile people, before and after migration. Ideal type 2 is interesting because we find here former "cosmopolites", highly mobile and educated men, who became settled, with most of their friends in Switzerland. Type 4 incorporates what we find in the literature described as "cosmopolites". Interestingly, both types show a low attachment to the country of origin. In other words, intensive circulation appears to loosen ties and feelings towards the country of origin. Something similar can be said for type 5, a very mobile group of less educated individuals; they are 'mobile non-attached', characteristics usually ascribed to highly educated individuals.

In other words, one-time migration that is the result of an economic crisis or low legal capital (no possibility to circulate) is linked to strong transnational attachment. Conversely, high mobility, when linked to high education and legal capital, leads to an attachment to Switzerland, whereas if it is linked to low education and legal capital, it leads to a type of non-attachment to anywhere. These results point to the fact that multiple factors affect the emergence and maintenance of transnationality and that they can be entangled with unexpected results.

Finally, our results not only point to the context dependency of transnationality but also highlight that studying a diverse migration population can occasionally reveal unexpected results and, specifically, allows nuancing a general hypothesis about transnationality. 


\section{References}

Al-Ali, N., Black, R., \& Koser, K. (2001). The limits to 'transnationalism': Bosnian and Eritrean refugees in Europe as emerging transnational communities. Journal of Ethnic and Migration Studies, 24(4), 578-600.

Basch, L., Glick Schiller, N., \& Szanton Blanc, C. (1994). Nations unbound: Transnational projects, postcolonial predicaments, and deterritorialized nation-states. New York: Gordon and Breach.

Beck, U., \& Sznaider, N. (2006). Unpacking cosmopolitanism for the social sciences: A research agenda. The British Journal of Sociology, 57(1), 1-23.

Boyd, M. (1989). Family and personal networks in international migration: Recent developments and new agendas. International Migration Review, 23(3), 638-670.

Chavel, S. (2014). De la migration à la mobilité : Commer aller au-delà du nationalisme méthodologique? Presses de Sciences Po, 54(2), 53-66.

Cresswell, T. (2010). Towards a politics of mobility. Environment and Planning D: Society and Space, 28, 17-31.

Dahinden, J. (2005). Contesting transnationalism? Lessons from the study of Albanian migration networks from former Yugoslavia. Global Networks. A journal of transnational affairs, 5(2), 191-208.

Dahinden, J. (2009). Are we all transnationals now? Network transnationalism and transnational subjectivity: The differing impacts of globalization on the inhabitants of a small Swiss city. Ethnic and Racial Studies, 32(8), 1365-1386.

Dahinden, J. (2010a). "Cabaret dancers - settling down in order to stay mobile"? Bridging theoretical orientations within transnational migration studies. Social Politics. International Studies in Gender, State \& Society, 17(3), 323-348.

Dahinden, J. (2010b). The dynamics of migrants' transnational formations: Between mobility and locality. In R. Bauböck \& T. Faist (Eds.), Transnationalism and diaspora. Concept, theories and methods (pp. 51-72). Amsterdam: Amsterdam University Press.

Dahinden, J. (2012). Transnational belonging, non-ethnic forms of identification and diverse mobilities: Rethinking migrant integration. In M. Messer, R. Schroeder, \& R. Wodak (Eds.), Migration: Interdisciplinary perspectives (pp. 117-128). Wien: Springer.

Dahinden, J. (2016). A plea for the 'de-migranticization' of research on migration and integration. Ethnic and Racial Studies, 39(13), 2207-2225.

Faist, T. (2000). Transnationalization in international migration: Implications for the study of citizenship and culture. Ethnic and Racial Studies, 23(2), 189-222.

Faist, T. (2013). The mobility turn: A new paradigm for the social sciences? Ethnic and Racial Studies, 36(11), 1637-1646. https://doi.org/10.1080/01419870.2013.812229.

Faist, T., Fauser, M., \& Reisenauer, E. (2013). Transnational migration. Cambridge: Polity Press.

Favell, A. (2008). Eurostars and Eurocities: Free movement and mobility in an integrating Europe. Malden: Blackwell.

Gazareth, P., \& Modetta, C. (2006). Intégration et réseaux sociaux. Déterminants de l'isolement social en Suisse. Neuchâtel: Office fédéral de la statistique.

Glick Schiller, N. (2004). Transnationality. In D. Nugent \& J. Vincent (Eds.), A companion to the anthropology of politics. Oxford: Blackwell Publishing.

Glick Schiller, N., \& Salazar, N. B. (2013). Regimes of mobility across the globe. Journal of Ethnic and Migration Studies, 39(2), 183-200.

Glick Schiller, N., Basch, L., \& Blanc-Szanton, C. (Eds.). (1992). Towards a transnational perspective on migration: Race, class, ethnicity, and nationalism reconsidered (Annals of the New York Academy of Sciences). New York: The New York Academy of Sciences. 
Glick Schiller, N., Basch, L., \& Blanc, C. S. (1995). From immigrant to transmigrant: Theorizing transnational migration. Anthropological Quarterly, 68(1), 48-63.

Gowricharn, R. (2009). Changing forms of transnationalism. Ethnic and Racial Studies, 32(9), $1619-1638$.

Guarnizo, L. E., Portes, A., \& Haller, W. (2003). Assimilation and transnationalism: Determinants of transnational political action among contemporary migrants. American Journal of Sociology, 108(6), 1211-1248.

Herz, A., \& Olivier, C. (2012). Transnational social networks - Current perspectives. Transnational Social Review, 2(2), 115-119. https://doi.org/10.1080/21931674.2012.10820729.

Hochschild, A. R. (1983). The managed heart. Berkeley: University of California.

Hui, A. (2016). The boundaries of interdisciplinary fields: Temporalities shaping the past and future of dialogue between migration and mobilities research. Mobilities, 11(1), 66-82.

Itzigsohn, J., \& Gioguli Saucedo, S. (2005). Incorporation, transnationalism, and gender: Immigrant incorporation and transnational participation as gendered process. International Migration Review, 39(4), 895-920.

Kivisto, P. (2001). Theorizing transnational immigration: A critical review of current efforts. Ethnic and Racial Studies, 24(4), 549-577.

Levitt, P., \& Glick Schiller, N. (2004). Conceptualizing simultaneity: A transnational social field perspective on society. International Migration Review, 38(3), 1002-1039. https://doi. org/10.1111/j.1747-7379.2004.tb00227.x.

Levitt, P., \& Jaworsky, N. (2007). Transnational migration studies: Past development and future trends. Annual Review of Sociology, 33(7), 1-28. https://doi.org/10.1146/annurev. soc.33.040406.131816.

Massey, D. S., Arango, J., Graeme, H., Kouaouci, A., Pellegrino, A., \& Taylor, J. E. (1993). Theories of international migration: A review and appraisal. Population and Development Review, 19(3), 431-466.

Moret, J. (2015). Cross-border mobility, transnationality and ethnicity as resources: European Somalis' post-migration mobility practices. Journal of Ethnic and Migration Studies, 42(9), 1-18. https://doi.org/10.1080/1369183X.2015.1123089.

Moret, J. (2018). European Somalis: From migration to mobility capital. Cross-Border Movements and the Transnational Circulation of Resources. Springer.

Portes, A., Guarnizo, L. E., \& Landolt, P. (1999). The study of transnationalism: Pitfalls and promise of an emergent research field. Ethnic and Racial Studies, 22(2), 217-237.

Portes, A., Haller, W. J., \& Guarnizo, L. E. (2002). Transnational entrepreneurs: An alternative form of immigrant economic adaptation. American Sociological Review, 67(2), 217-237.

Pries, L. (2008). Transnational societal spaces: Which unites of analysis, reference, and measurement? In L. Pries (Ed.), Rethinking transnationalism, the meso-link of organisations (pp. 1-20). London/New York: Routledge.

Ryan, L. (2015). Friendship-making: Exploring network formations through the narratives of Irish highly qualified migrants in Britain. Journal of Ethnic \& Migration Studies, 41(10), 1664 1683. https://doi.org/10.1080/1369183X.2015.1015409.

Schapendonk, J. (2015). What if networks move? Dynamic social networking in the context of African migration to Europe. Population, Space and Place, 21(8), 809-819. https://doi. org/10.1002/psp. 1860 .

Snel, E., Hart, M., \& Van Bochove, M. (2016). Reactive transnationalism: Homeland involvement in the face of discrimination. Global Networks, 16(4), 511-530. https://doi.org/10.1111/ glob. 12125.

Urry, J. (2007). Mobilities. Cambridge: Polity Press.

Vertovec, S. (2009). Transnationalism. Key Ideas. London/New York: Routledge.

Waldinger, R. (2015). The cross-border connection. Immigrants, emigrants and their homelands. Cambridge: Harvard University Press. 
Waldinger, R., \& Fitzgerald, D. (2004). Transnationalism in question. American Journal of Sociology, 109(5), 1177-1195.

Wessendorf, S. (2010). Local attachments and transnational everyday lives: Secondgeneration Italians in Switzerland. Global Networks, 10(3), 365-382. https://doi. org/10.1111/j.1471-0374.2010.00293.x.

Wimmer, A., \& Glick Schiller, N. (2002). Methodological nationalism and beyond: Nation-state building, migration and the social sciences. Global Networks, 2(4), 301-334.

Open Access This chapter is licensed under the terms of the Creative Commons Attribution 4.0 International License (http://creativecommons.org/licenses/by/4.0/), which permits use, sharing, adaptation, distribution and reproduction in any medium or format, as long as you give appropriate credit to the original author(s) and the source, provide a link to the Creative Commons licence and indicate if changes were made.

The images or other third party material in this chapter are included in the chapter's Creative Commons licence, unless indicated otherwise in a credit line to the material. If material is not included in the chapter's Creative Commons licence and your intended use is not permitted by statutory regulation or exceeds the permitted use, you will need to obtain permission directly from the copyright holder.

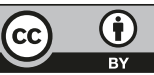

